\title{
Effect of Bio Fertilizer on Yield and Yield Attributes Characteristic of Field Pea (Pisum sativum L.) under Irrigated Condition
}

\author{
Harendra Kumar ${ }^{1 *}$, Naushad Khan', Vipin Kumar² and Akansha Singh ${ }^{2}$ \\ ${ }^{1}$ Department of Agronomy' Chandra Shekhar Azad University of Agriculture \& Technology, \\ Kanpur, (U.P.), India \\ ${ }^{2}$ Department of Soil Science, Sardar Vallabhbhai Patel University of Agriculture and \\ Technology, Meerut, India \\ *Corresponding author
}

\section{A B S T R A C T}

\begin{tabular}{|l|}
\hline $\begin{array}{l}\text { Ke y w or d s } \\
\text { Pea, Bio fertilizer } \\
\text { and Soil health }\end{array}$ \\
\hline Article Info \\
\hline $\begin{array}{l}\text { Accepted: } \\
\text { 17 January } 2021 \\
\text { Available Online: } \\
\text { 10 February } 2021\end{array}$ \\
\hline
\end{tabular}

An experiment "Effect of Bio Fertilizer on yield and yield attributes characteristic of Field Pea (Pisum sativum L.) Under Irrigated Condition was undertaken at Oil Seed Research Farm, Chandra Shekhar Azad University of Agriculture \& Technology, Kanpur during Rabi 2014- 2015. Experiment was conducted in Factorial Randomized Block Design with three replications. The highest yield was noticed in combined used of fertilizer of $\left(T_{1}\right)$ Rhizobium + PSB + PGPR (2051 kg/ha) followed by dual biofertilizer application of Rhizobium + PGPR (1958.33) and lowest yield was recorded in no inoculation (1543.33 $\mathrm{kg} / \mathrm{ha}$ ) followed by PGPR alone biofertilizer $(1561.67 \mathrm{~kg} / \mathrm{ha}$ ) as well as straw yield was also recorded highest from Rhizobium + PSB + PGPR $(2211.67 \mathrm{~kg} / \mathrm{ha})$ followed by Rhizobium + PGPR (2058.33) but least value of straw yield was obtained from PSB alone biofetilizer (1761.67 kg/ha) followed by Rhizobium alone biofertilizer $(1798.33 \mathrm{~kg} / \mathrm{ha})$.

\section{Introduction}

Pea (Pisum sativum L.) is one of the most important leguminous vegetable crops grown during winter season in Egypt for local consumption and export. According to FAO statistics, India is one of the largest producers of field pea in the world and stands at the 5th place in the list of major field pea producers next to France. The Indian production contributes to around $7 \%$ in the world's total produce with the production figures of 7.8 lakh tonnes. Uttar Pradesh is a major field pea producing state in India producing about $60 \%$ of the country's produce. The other major pea producing state in India is Madhya Pradesh. In Uttar Pradesh, Jalaun district contributes highest in terms of area and production by $21 \%$ and $29 \%$, respectively to the State total area and production of field pea. Again, Lalitpur stands at the second position in the area $(18 \%)$ and production (19\%) share to the state total, followed by Jhansi (area 14\% and production 14\%), Mahoba (area 8\% and production 5\%), Hamirpur (area 3\% and production 3\%) and Azamgarh (area 2\% and 
production 2\%). Rest $33 \%$ and $28 \%$ of acreage and output, respectively, are come from other states. (FAO, 2015). The pods of pea contain a great amount of protein and carbohydrates. So that, pea is considered as one of the most important sources in human nutrition. Fertilizers come in two types; they are either chemical or biofertilizers. It is an important frosty, hardy, annual, cool season pulse crop that is widely cultivated throughout the world. It is rich in protein and contains 20-25\% amino acid, sugar $12 \%$, carbohydrate, vitamin $\mathrm{A}$ and $\mathrm{C}$, calcium and phosphate and a small quantity of iron. Maintenance of seed quality during storage upto the next sowing season is difficult which depends upon several factors. Beside other abiotic and biotic factors responsible for qualitative and quantitative losses, the bruchids (Callosobruchus maculatus) cause severe damage resulting quantative losses varying from $10-15 \%$ including the reduction in germinability from 50-90\% (Singh et al., 2015). Biofertilizers play a very important role in improving soil fertility by fixing atmospheric nitrogen both in association with plant roots and without it, solubilize insoluble soil phosphates and produces plant growth substances in the soil. The inoculation of legume seed crops with associative N2-fixing bacteria led to change and improve plant growth and yield (Zaghloul et al., 2015). Biofertilizers are carrier-based inoculants containing cells of efficient strains of specific microorganisms (namely bacteria) used by farmers for enhancing the productivity of the soil by fixing atmospheric nitrogen or by solubilizing soil phosphate or by stimulating plant growth for synthesis of growth promoting substances. Biofertilizers play a main key role for selective adsorption of immobile $(\mathrm{P}, \mathrm{Zn}, \mathrm{Cu})$ and mobile $(\mathrm{C}, \mathrm{S}, \mathrm{Ca}$, $\mathrm{K}, \mathrm{Mn}, \mathrm{Cl}$, Bo, and $\mathrm{N}$ ) elements to plants. The rhizosphere bacteria secrete growth substances and secondary metabolite, which contribute to seed germination and plant growth. In recent years, free living bacteria Azotobacter, associate Azospirillum and symbiotic Rhizobium bacteria are gaining much popularity. Such practices are being encouraged to save the chemical fertilizers natural economy and the environment. The effect of inoculation of pea seeds with such bacteria for increased plant growth, yield and productivity. The significant effect of biofertilizers may be due to the effect of different strain groups and nutrients mobilizing microorganisms which help in availability of metals and their form in the composted material and increased levels of extractable minerals (Shafeek, et al., 2014). All the biofertilizers are safe, low cost and easy in application. Biofertilizer application has shown bright results in case of leguminous crops, especially exclusive results have been obtained in case of pea. Considering the above facts, present investigation was carried to find out the effect of bio-fertilizers on growth and yield of pea.

\section{Materials and Methods}

The experiment was laid out at Oil Seed Research Farm of Chandra Shekhar Azad University of Agriculture and Technology, Kanpur (U.P.) India during Rabi season of 2014-15. The farm is located in the main campus of the university. The field was well leveled having assured irrigation and drainage facilities. Thus, almost double cropping is done on most of the farm field. The experiment was laid out in Randomized Block design having main plots as dates of sowing and in sub-plot took varieties of filed pea. These were replicated four times and used lay out plan with actual allocation of treatments in different main and sub-plots. The soil of the experimental field was well drained, sandy loam in texture, slightly alkaline in reaction ( $\mathrm{pH}$ 7.77), low in available nitrogen, medium in available phosphorus and potassium with an electrical conductivity 
$0.30 \mathrm{dSm}^{-1}$. Eight treatments $\left[\mathrm{T}_{1}\right.$ Rhizobium +PSB+PGPR, $\mathrm{T}_{2}$ Rhizobium +PGPR, $\mathrm{T}_{3}$ Rhizobium +PSB, $\mathrm{T}_{4} \quad \mathrm{PSB}+\mathrm{PGPR}, \mathrm{T}_{5}$ Rhizobium, $\mathrm{T}_{6}$ PGPR, $\mathrm{T}_{7} \mathrm{PSB}$ and $\mathrm{T}_{8}$ No inoculation] were tested in RBD with three replication common dose of phosphorus and potassium was applied in each treatments.

\section{Results and Discussion}

Effect of different biofertilizer on yield attributes characteristics

The values related to the effect of different biofertilizer on Number of pod plant ${ }^{-1}$ of field pea have been presented in Table 1 and Fig. 1. It is apparent from the data given in Table showed that the number of pod plant ${ }^{-1}$ was not affected significantly by different biofertilizer. The number of pod per plant was noticed statistically highest in Rhizobium + PSB+ PGPR treated plots (14.33) but lowest in no inoculation of biofertilzer (9.00). The number of pod was also found more in Rhizobium + PGPR, Rhizobium + PSB and Rhizobium + PGPR i.e. 12.67, 12.33 and 12.0, respectively. The number of pod were also observed least in Rhizobium, PGPR and PSB alone treated plots of field pea during the study period. The values related to the effect of different biofertilizer on number of grain $\operatorname{pod}^{-1}$ of field pea have been presented also in Table. It is obvious from the data given in Table showed that the number of grain pod $^{-}$ ${ }^{1}$ was not affected significantly by different biofertilizer.

The number of grain per pod was scored highest value in Rhizobium + PSB + PGPR treated plot of field pea (6.33) as well as similar value of number of grain per pod were achieved in Rhizobium + PGPR and Rhizobium + PSB treatments (6.00). Whereas, the lowest values of number of grain per pod was notice in PGPR alone (4.33) followed by PSB alone treatments (5.00). The values related to the effect of different biofertilizer on 100 grain weight $(\mathrm{g})$ or Test Weight of field pea has been presented in Table 1. It is apparent from the data given in Table showed that the 100 grain weight (g) was influenced significantly by different biofertilizer. The 100 grain weight was observed significantly highest under Rhizobium + PSB + PGPR (19.82g) followed by Rhizobium + PSB (19.45g) then Rhizobium alone (19.21) and PSB alone $(19.20 \mathrm{~g})$, respectively. The lowest value of 100 grain weight $(\mathrm{g})$ was noticed in no inoculation treatment $(18.28 \mathrm{~g})$ followed by PGPR alone treatment (18.54g) during the observation period.

Table.1 Effect of different biofertilizer on number of grain $\operatorname{pod}^{-1}$ number of pod/plant and test weight $(\mathrm{g})$ of field pea

\begin{tabular}{|l|c|c|c|}
\hline Treatments & Number of grain pod $^{\mathbf{1}}$ & Number of pod plant $^{\mathbf{1}}$ & Test Weight $^{(g)}$ \\
\hline $\mathbf{T}_{\mathbf{1}}$ (Rhizobium +PSB+PGPR) & 6.33 & 14.33 & 19.82 \\
\hline $\mathbf{T}_{\mathbf{2}}$ (Rhizobium +PGPR) & 6.00 & 12.67 & 19.21 \\
\hline $\mathbf{T}_{\mathbf{3}}$ (Rhizobium +PSB) & 6.00 & 12.33 & 19.45 \\
\hline $\mathbf{T}_{\mathbf{4}}$ (PSB+PGPR) & 5.67 & 12.00 & 18.78 \\
\hline $\mathbf{T}_{\mathbf{5}}$ ( Rhizobium) & 5.33 & 11.00 & 19.33 \\
\hline $\mathbf{T}_{\mathbf{6}}$ (PGPR) & 4.33 & 10.67 & 18.54 \\
\hline $\mathbf{T}_{\mathbf{7}}$ (PSB) & 5.00 & 10.00 & 19.20 \\
\hline $\mathbf{T}_{\mathbf{8}}$ (No inoculation) & 4.67 & 9.00 & 18.28 \\
\hline SE(d) & 1.55 & 2.08 & 0.09 \\
\hline CD (p=0.05) & N.S. & N.S. & 0.20 \\
\hline
\end{tabular}


Table.2

\begin{tabular}{|c|c|c|}
\hline Treatments & Grain yield $\left(\mathrm{kgha}^{-1}\right)$ & Straw yield $\left(\mathrm{kg} / \mathrm{ha}^{-1}\right)$ \\
\hline $\mathrm{T}_{1}($ Rhizobium +PSB+PGPR) & 2051.00 & 2211.67 \\
\hline $\mathbf{T}_{2}($ Rhizobium +PGPR) & 1958.33 & 2058.33 \\
\hline $\mathrm{T}_{3}($ Rhizobium +PSB $)$ & 1845.00 & 1986.67 \\
\hline $\mathrm{T}_{4}(\mathrm{PSB}+\mathrm{PGPR})$ & 1813.33 & 2023.33 \\
\hline $\mathbf{T}_{5}$ (Rhizobium) & 1636.67 & 1798.33 \\
\hline $\mathrm{T}_{6}(\mathrm{PGPR})$ & 1561.67 & 1845.00 \\
\hline $\mathbf{T}_{7}$ (PSB) & 1615.33 & 1761.67 \\
\hline $\mathbf{T}_{8}$ (No inoculation) & 1543.33 & 1880.00 \\
\hline SE(d) & 37.68 & 52.48 \\
\hline $\mathrm{CD}(\mathrm{p}=\mathbf{0 . 0 5})$ & N.S. & 113.67 \\
\hline
\end{tabular}

Fig.1 Effect of different biofertilizer on number of grain pod-1 number of pod/plant and test weight $(\mathrm{g})$ ) of field pea
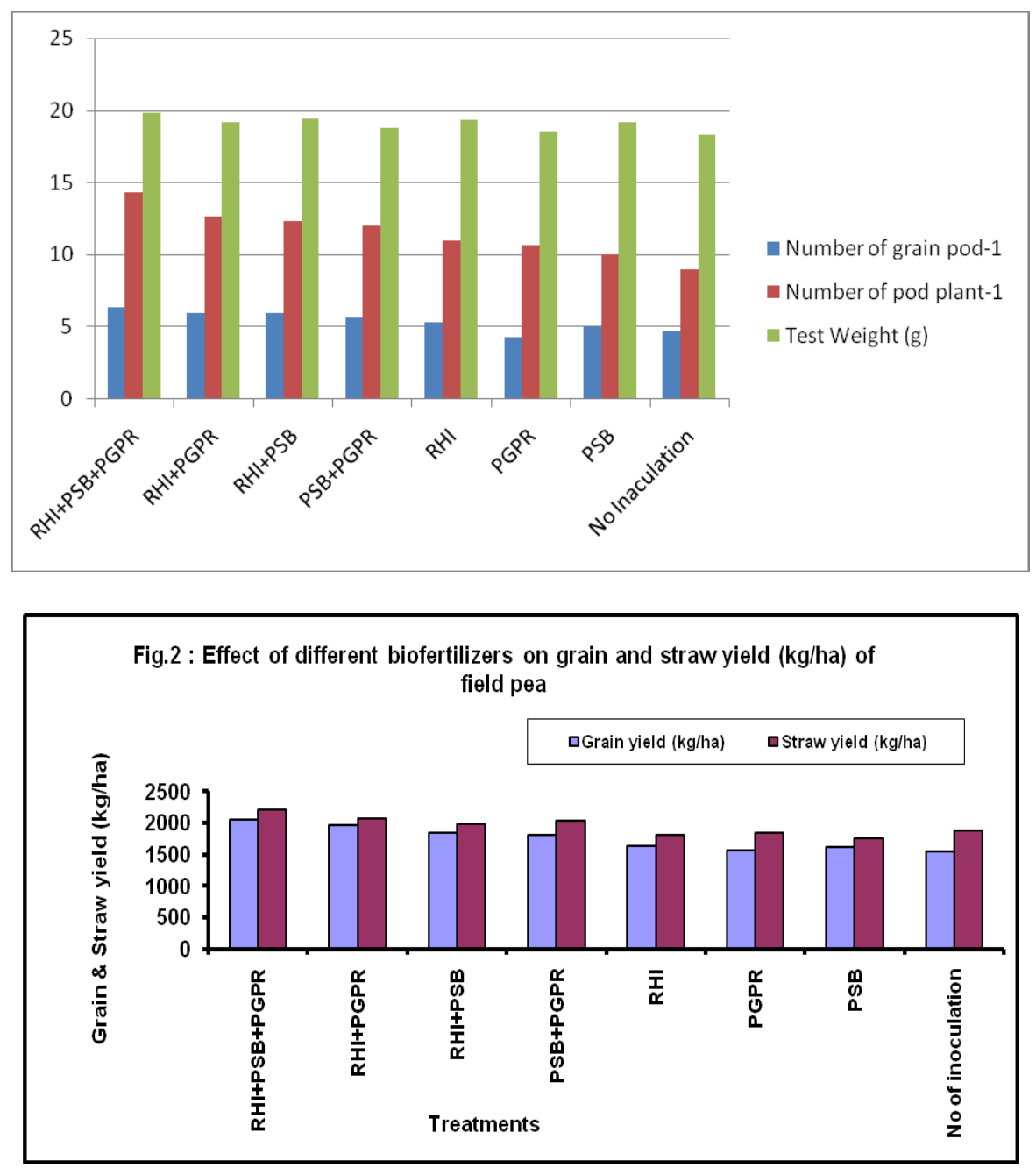
Effect of different biofertilizer on grain and straw yield $\left(\mathrm{kgha}^{-1}\right)$ of field pea

The grain yield $\left(\mathrm{kgha}^{-1}\right)$ was recorded significantly highest under Rhizobium + PSB + PGPR (2051.00 $\left.\mathrm{kgha}^{-1}\right)$ treatment followed by Rhizobium + PGPR (1958.33 $\left.\mathrm{kgha}^{-1}\right)$ as compared to no inoculation treatment (1543.33 $\mathrm{kgha}^{-1}$ ) followed by PGPR alone $\left(1561.67 \mathrm{kgha}^{-}\right.$ $\left.{ }^{1}\right)$. The Rhizobium + PSB (1845.00 $\left.\mathrm{kgha}^{-1}\right)$ and PSB + PGPR (1813.33 $\left.\mathrm{kgha}^{-1}\right)$ were recorded second highest value of the grain yield (Fig. 2). The values related to the effect of different biofertilizer on straw yield $\left(\mathrm{kgha}^{-1}\right)$ of field pea have been presented in Table 2. It is obvious from the data given in Table 2 showed that the straw yield $\left(\mathrm{kgha}^{-1}\right)$ was influenced significantly by different biofertilizer. The data showed in Table revealed that the straw yield $\left(\mathrm{qha}^{-1}\right)$ was significantly highest in Rhizobium + PSB+ PGPR (2211.67 $\mathrm{qha}^{-1}$ ) followed by Rhizobium + PGPR (2058.33 $\mathrm{qha}^{-1}$ ) and PSB + PGPR $\left(2023.33 \mathrm{qha}^{-1}\right)$. While least value was noticed in PSB alone (1761.67 $\mathrm{qha}^{-1}$ ) followed by Rhizobium alone (1798.33 qha $\left.^{-1}\right)$.Rhizobium + PSB (1986.67 $\left.\mathrm{qha}^{-1}\right)$, no inoculation (1880.00qha ${ }^{-1}$ ) and PGPR (1845.00 $\mathrm{qha}^{-1}$ ) were also observed $2^{\text {nd }}$ highest straw yield $\left(\mathrm{qha}^{-1}\right)$.

From the result obtained in the present study it may be concluded that the highest yield was noticed in combined use of biofertilizer i.e. Rhizobium + PSB + PGPR (2051 kg/ha) followed by dual biofertilizer application i.e. Rhizobium + PGPR (1958.33kg/ha). the lowest yield was recorded in no inoculation (1543.33 $\mathrm{kg} / \mathrm{ha}$ ) followed by PGPR alone biofertilizer $(1561.67 \mathrm{~kg} / \mathrm{ha})$ as well as straw yield was also recorded highest from Rhizobium + PSB + PGPR $(2211.67 \mathrm{~kg} / \mathrm{ha})$ followed by Rhizobium + PGPR (2058.33) but least value of straw yield was obtained from PSB alone biofetilizer (1761.67 kg/ha) followed by Rhizobium alone biofertilizer $(1798.33 \mathrm{~kg} / \mathrm{ha})$.

\section{References}

Rashed Zaghloul, Rasha El-Meihy and Hamed Abou-Aly. (2015) Improvement of Growth and Yield of Pea Plants Using Integrated Fertilization Management June 2015, Universal Journal of Agricultural Research 3(4): 135-143.

Shabeer Ahmad Rather, Mir Aashiq Hussain and Narinder Lal Sharma (2010). Effect of bio-fertilizers on growth, yield and economics of field pea (Pisum sativum L.). International Journal of Agricultural Sciences, 6 (1):65-66.

Singh, A.K.; Chaudhary, R.K. and Sharma, R.P.R. (1993). Effect of inoculation and fertilizer levels on yield, yield attributes and nutrient uptake of greengram (Phaseolus radiatus) and blackgram ( $P$. mungo). Indian Journal of Agronomy. 38(4): 663-666.

Singh, A.P., Chaturvedi, Sumit, Tripathi, M.K and Singh, S. (2015). Growth and yield of greengram [Phasolus radiata (L.) Wilczek] as influenced by biofertilizer and phosphorus application. Annuals, of Biology. 20(2): 227-232.

Singh, B. and Pareek, R.G. (2003). Effect of P and biofertilizers on growth and yield of moongbean. Indian Journal of Pulses Research. 16(1): 3 1-33.

Singh, B. and Pareek, R.G. (2003). Studies on phosphorus and bio-inoculation on biological nitrogen fixation, concentration, uptake, quality and productivity of mungbean, Annals of Agricultural Research, 24(3): 537-541

\section{How to cite this article:}

Harendra Kumar, Naushad Khan, Vipin Kumar and Akansha Singh. 2021. Effect of Bio Fertilizer on Yield and Yield Attributes Characteristic of Field Pea (Pisum sativum L.) under Irrigated Condition. Int.J.Curr.Microbiol.App.Sci. 10(02): 2189-2193. doi: https://doi.org/10.20546/ijcmas.2021.1002.260 